\title{
EFFECT OF THE EXISTENCE OF CITY PARK COMMUNITY SATISFACTION IN INFRASTRUCTURE DEVELOPMENT (CASE STUDY: CITY SURABAYA)
}

\author{
Nanda Putri Ayuningtyas
}

\author{
F. Rooslan Edy Santosa
}

\begin{abstract}
The title: the influence of the existence of the park city on public satisfaction in building Infrastructures (case studies: city of Surabaya) town is a human dwellings that is the manifestation of the planning and design infested by share elements such as building, road and green open space (brickerhoff john jackson). The city will always experience a progression from time to time the which includes various dimensions among others, political dimension, social, economic, culture and technology and physical.One of the needs of the urban population is the availability of the physical area of public space. Public Space Every City expected to conduct the arrangement of the area of public space, and composed in the Regional Landscaping Plan (RTRW) City. For the development of the city was reflected by the development of the city physically through the growth of infrastructure in the life support urban residents. This study using the data from 100 respondents primary .Linear using regression analysis techniques that analysis using multiple analysis (SPSS statistical products and services) solution. We do the validity and reliability, the classic test (covering the normality, the autocorrelation, heteroscedasticity) use SPSS test .so that it can be concluded that the city of surabaya people most satisfied and comfortable on the infrastructure of the city.
\end{abstract}

Keywords: infrastructure development, Surabaya city park

\section{INTRODUCTION}

City is a place of abode of human beings that is the manifestation of the planning and design element as though full of share, roads and green open space john (jackson brickerhoff, 1984) .City will always experience the developments from time to time the which includes various dimensions among others dimensions political, social, economic, culture, and technology and physical.One the physical needs of urban community has been the availability of public space (public space) .each city expected the public space, area and composed in the spatial spatial (city). So far reflected by the development of city development the physically through community growth and other life-supporting infrastructure facilities

The development of Cities tended to the physical way without accompanied by an awareness of the construction of the environment has led to the dilemma very lack of the public space in urban areas. Whereas if further, has been reviewed restaurants the balance of the urban environment as important as physical and economic growth. cityln drawing up spatial plans, city a city is expected to provide and the make use of green open space and public ruangterbuka.According to law no.26 years, 2007, the provision of the area for green open space and the public space in a region of the city, at least $40 \%$, an area in the town of with the proportion of $30 \%$ to green open space and how much $10 \%$ to the open public. 
The management of urban areas is a term of the which is translated of the urban management who is one of the Cities of unhcs years 1960 (united respectively to keep Reviews their sponsored by the center for human settlements), a society together the united nations that looked at urban the said matters and settlement. Is now Analyzed hear and to comprehend and the management of urban areas as an attempt the expected Mobilization of urban resources by stages of planning, the implementation of the, the cost of maintenance, on the control of, efficiently and Effectively in order to to Realize Reviews their vision, the mission, and of the purpose of of an area with urban areas continue to maintain strategic environment.

\section{Literature}

Review system infrastructure defined as facilities or the basic structure, equipment, assembly constructed and required to functioning of the system of social and economic community system (grigg, 2000 in kodoatie 2005) .System infrastructure system was a play social and economic system in society. Infrastructure play an important role as mediators between economic and social system in order that human life and environment.It harmonisation the stable in meaning not deficient infrastructure (impact in humans), but not excessive Also Regardless of the nature of the support environment being to spoil the and Eventually impact to people and other things in this, was a system of the natural environment, infrastructure and economic infrastructure system, supported by the system of a social system as an object and targets supported by the economic system.

Infrastructure system defined as facilities or fundamental structure, equipment, an installation constructed and needed to functioning of the system of social and economic system (grigg community, 2000 in kodoatie,) 2005 .Infrastructure system system was a major social and economic system in society.

Infrastructure important as mediators between economic and social system in order human life and the environment. The harmonisation of life to stay awake in terms of infrastructure no lack of (resulted in humans), but not excessive Also Regardless of the natural environment would undermine the capacity for Also the nature and impact Eventually people and other things in this case, the natural environment is supporting infrastructure systems, and economic system supported by infrastructure system, social system as objects and targets of supported by the economic system.

\section{Vegetation criteria for RTH (Green Open Space) Wildlife and Parks}

Criteria for selecting vegetation to neighborhood parks and city parks are as follows:

a. Non-toxic, prickly, not easily broken branches, roots do not interfere with the foundation.

b. Heading quite shady and compact, but not too dark

c. Varying plant heights, green color with another color variation balanced

d. Stature and quite beautiful crown shape

e. Growth rate was

f. Habitat in the form of local plants and crops

g. Kinds of annual or seasonal crops

h. Spacing half of the meeting so as to produce the optimal shade

i. Resistant to pests and diseases of plants

j. Able to absorb air pollution

k. As much as possible is a plant that invite birds

(Regulation of the Minister of Public Works, 2008) 


\section{METHODOLOGY}

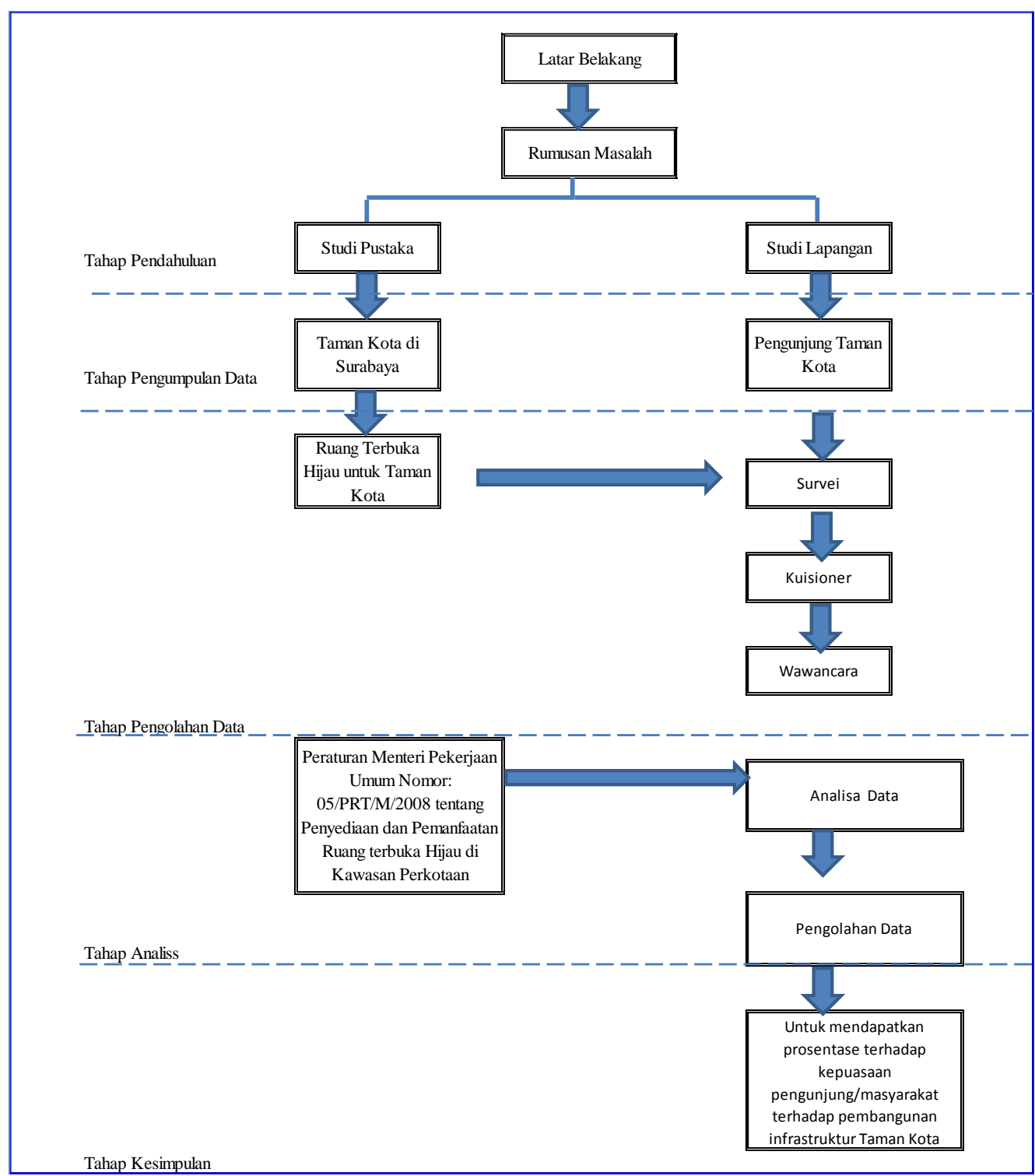

Figure 1. Research Methodology

\section{RESULTS AND DISCUSSION}

The characteristic feature of the respondents in this study is divided into five parts consisting of :

1. Type

Respondents by sex can be classified into two groups: men and women can be seen in the table and graph below.

\begin{tabular}{cccccc}
\multicolumn{6}{c}{ Table 1. Respondents' Gender } \\
\hline & frequency & Percent & valid Percent & $\begin{array}{c}\text { Cumulative } \\
\text { Percent }\end{array}$ \\
\hline \multirow{4}{*}{ valid } & woman & 58 & 58.0 & 58.0 & 58.0 \\
& Man & 42 & 42.0 & 42.0 & 100.0 \\
& Total & 100 & 100.0 & 100.0 & \\
\hline
\end{tabular}




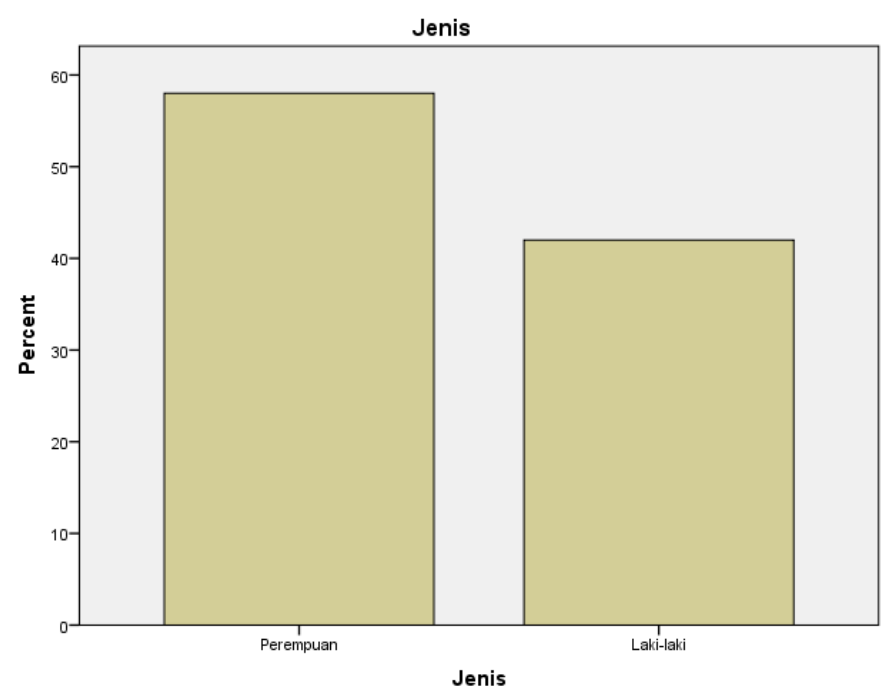

Figure 2. Graphical Gender respondents

According to the table and the graph above it can be seen that most respondents adaah respondents with female sex that as many as 58 people or $58 \%$, while respondents with male gender as much as 48 or $48 \%$.

\section{Age}

Respondents by age can be classified into five groups: age less than 17 years, age 17-25 years, age 26-45 years, 46-65 years of age and over 65 years of age can be seen in the following tables and graphs.

Table 2. Age of Respondents

\begin{tabular}{cccccc}
\hline & & frequency & Percent & valid Percent & $\begin{array}{c}\text { Cumulative } \\
\text { Percent }\end{array}$ \\
\hline \multirow{4}{*}{ valid } & $17-25$ & 27 & 27.0 & 27.0 & 27.0 \\
& $<17$ & 23 & 23.0 & 23.0 & 50.0 \\
& $26-45$ & 21 & 21.0 & 21.0 & 71.0 \\
& $45-65$ & 19 & 19.0 & 19.0 & 90.0 \\
& $>65$ & 10 & 10.0 & 10.0 & 100.0 \\
& Total & 100 & 100.0 & 100.0 & \\
\hline
\end{tabular}

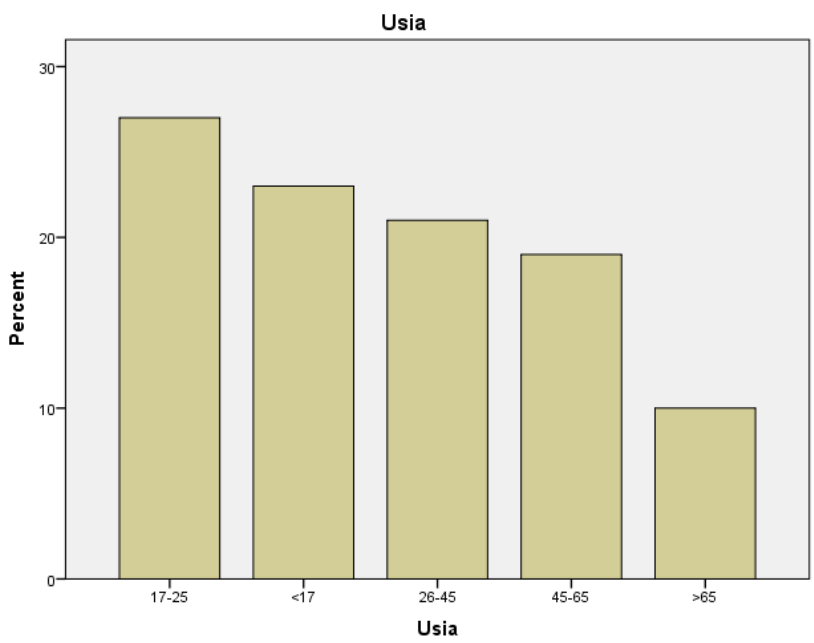

Figure 3. Chart Age Respondents 
According to the table and the graph above it can be seen that by the age of the respondents can be seen that most respondents are in the age of 17-25 years that as many as 27 respondents or $27 \%$, and then at age less than 17 years that as many as 23 people or $23 \%$, diiukuti by respondents in age $26-45$ years as many as 21 people or $21 \%$, then people aged $45-65$ years as many as 19 people or $19 \%$, and the least is people aged more than 65 years that as many as 10 people or $10 \%$.

\section{Work}

Respondents based their work can be grouped into five groups, namely students / students, civil servants, private, Self and others that can be seen in the table and graph below.

Table 3. Respondents Jobs

\begin{tabular}{cccccc}
\hline & & frequency & Percent & valid Percent & $\begin{array}{c}\text { Cumulative } \\
\text { Percent }\end{array}$ \\
\hline \multirow{4}{*}{ valid } & & & & 42.0 \\
& Student / Student & 42 & 42.0 & 42.0 & 60.0 \\
& Private & 18 & 18.0 & 18.0 & 76.0 \\
& entrepreneur & 16 & 16.0 & 16.0 & 91.0 \\
& PNS & 15 & 15.0 & 15.0 & 100.0 \\
& more & 9 & 9.0 & 9.0 & \\
\hline
\end{tabular}

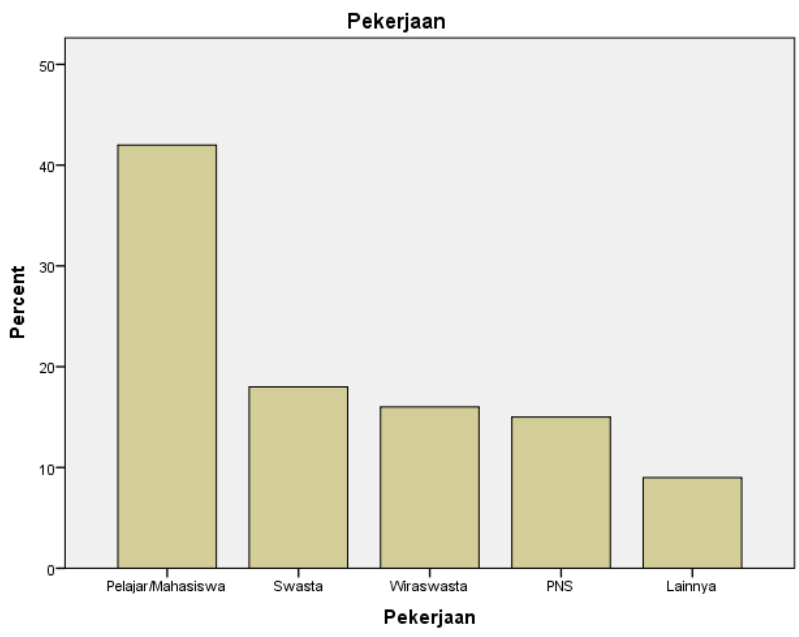

Figure 4. Graph respondents work

According to the table and the graph above we can see that based on the work of respondents can be seen that most respondents are respondents with jobs schoolchildren / students that as many as 42 respondents or $42 \%$, then the private jobs that as many as 18 people or $18 \%$, diiukuti by respondents with the work of self-employed as many as 16 people or $16 \%$, then the respondents with the work of civil servants as many as 15 people or $15 \%$, and the least is the respondents with the work of others that as many as 9 people or $9 \%$.

\section{Level of education}

Respondents by level of education can be grouped into six groups: elementary, junior high, high school, S1, S2 and S3, but no respondents with primary and secondary education level results can be seen in the table and graph below. 
Table 3. Respondents Education Level

\begin{tabular}{|c|c|c|c|c|c|}
\hline & & frequency & Percent & valid Percent & $\begin{array}{c}\text { Cumulative } \\
\text { Percent }\end{array}$ \\
\hline \multirow{5}{*}{ valid } & $\begin{array}{l}\text { High } \\
\text { School }\end{array}$ & 76 & 76.0 & 76.0 & 76.0 \\
\hline & S1 & 13 & 13.0 & 13.0 & 89.0 \\
\hline & S2 & 9 & 9.0 & 9.0 & 98.0 \\
\hline & S3 & 2 & 2.0 & 2.0 & 100.0 \\
\hline & Total & 100 & 100.0 & 100.0 & \\
\hline
\end{tabular}

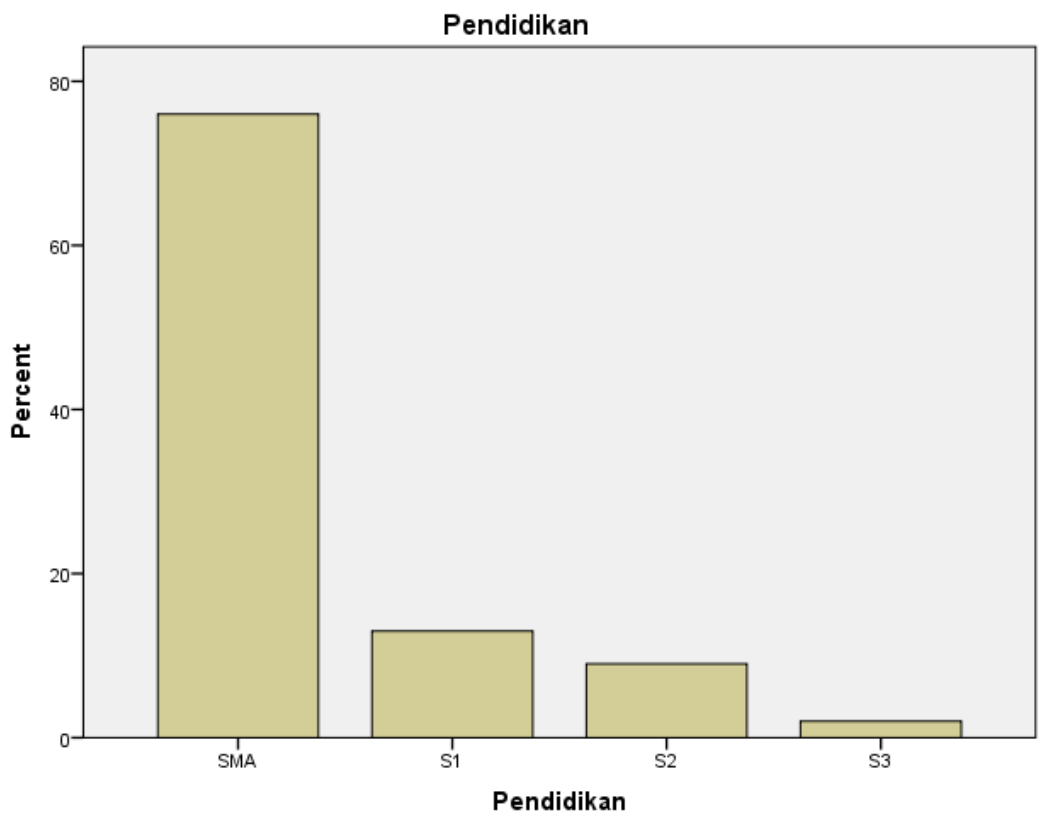

Figure 5. Graph Respondents Education Level

According to the table and the graph above it can be seen that by education level of respondents can be seen that most respondents are respondents to the level of a high school education that is as much as 76 respondents or $76 \%$, a level $\mathrm{S} 1$ that as many as 13 people or $13 \%$, diiukuti by respondents with education level S2 as many as 9 people or $9 \%$, and the least is the respondents with education level S3 that as many as 2 or $2 \%$.

\section{Tourist destination}

Respondents by travel destination can be grouped into five groups, namely recreational / sightseeing, sports, buy food, sell and others that can be seen in the table and graph below.

Table 4. Objectives of respondents travel

\begin{tabular}{|c|c|c|c|c|c|}
\hline & & frequency & Percent & $\begin{array}{c}\text { valid } \\
\text { Percent }\end{array}$ & $\begin{array}{c}\text { Cumulative } \\
\text { Percent }\end{array}$ \\
\hline \multirow{4}{*}{ valid } & $\begin{array}{l}\text { Recreation / } \\
\text { Streets }\end{array}$ & 41 & 41.0 & 41.0 & 41.0 \\
\hline & Sports & 29 & 29.0 & 29.0 & 70.0 \\
\hline & Buying food & 20 & 20.0 & 20.0 & 90.0 \\
\hline & vend & 6 & 6.0 & 6.0 & 96.0 \\
\hline
\end{tabular}




\begin{tabular}{lrrrr}
\hline Etc & 4 & 4.0 & 4.0 & 100.0 \\
Total & 100 & 100.0 & 100.0 & \\
\hline
\end{tabular}

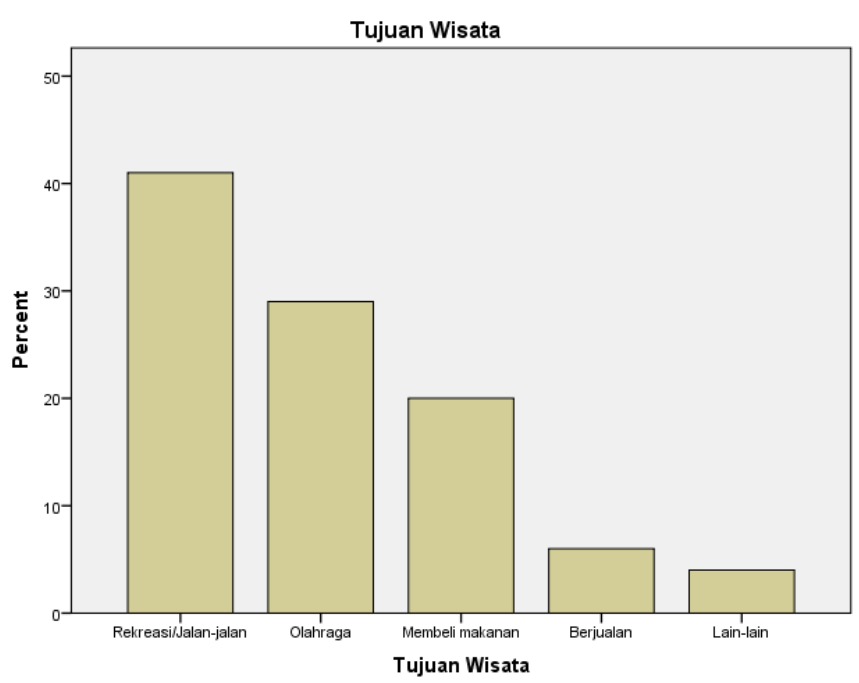

Figure 6. Graph Destination Respondents

According to the table and the graph above it can be seen that based tourist destination of respondents to a city park Surabaya can be seen that most respondents are respondents with travel destination recreation / sightseeing that as many as 41 respondents or $41 \%$, then the respondent with the purpose of sports tourism that as many as 29 people or $29 \%$, followed by respondents with tourist destinations and buy food as much as 20 or $20 \%$, then the respondent with a tourist destination to sell as many as 6 or $6 \%$, and the least is the respondents to tourist destinations, etc. that as many as 4 people or $4 \%$.

Based on the research findings, the people of Surabaya are very satisfied with the development of a city park. The results of the questionnaire showed the beauty aspect where most people vote against the condition and availability of the facilities available in the garden area is very good and complete. Diarea garden plants also have an aesthetic element that is worth a look coupled with good lighting garden lights when the night makes the city look very beautiful park existence. Results of interviews with some of the visitors that they are on average found the beauty of the city park in Surabaya is very good with the reason given is kondsi well manicured gardens, complete facilities in good condition, selection of plants in the garden area is also gorgeous and lighting that illuminate the park also add to the beauty of the garden.

In the aspect of cleanliness ratings Surabaya community is also very good. This is indicated by the results of a questionnaire in which most of the community assess the condition and availability of clean water and plenty diarea park then cleanliness in the garden area is also very good and the condition of the drains located at the park was also good. Interviews with several visitors also mostly said that the condition of the park area is very clean because of the condition of either or clean water then water is also available around the park and the water channel organized well and always clean. It stretcher strengthened by the results of a questionnaire which showed kebrsihan Surabaya city park in the community category is very convenient for the city of Surabaya.

On security aspects of the community assessment that the security situation is very safe neighborhood park area. The results of the questionnaire showed that the level of security of the facility in the garden area is very safe / well. Then the security area around the park when people do good facilities too. Interview visitors also showed that they felt safe beradadi garden area for play facilities also meet the security elements as well as a garden area kondsi when activity is not concerned about his safety. So the results of the 
questionnaire on the security aspects in the category very convenient for the city of Surabaya.

In the aspect of public access is also very good ratings. People feel access to the location of the park is very easy. Convenience was also obtained in the activities in the park. Another thing is also equally important is security parking is also very easy to do. Interviews showed that access to the garden area is considered very good for the people of Surabaya. The reason given is because of its strategic location, activity is also easy to do because wellorganized and very easy vehicle parking. The results showed that the aspect of access kuesionerpun city park are in the category of very convenient for the people of Surabaya.

In the aspect of the form of a city park, the community has been very good judge. The results of the questionnaire showed that most respondents assess the condition of facilities and infrastructure is good and complete. Neither the plant condition diarea parks, community assess the arrangement has been very good. Interview will also show most of the people or visitors are matched to the shape of a city park that is seen from the facilities and infrastructure as well as a complete and well-established plants and neat. Questionnaire results also show that the aspect form the city park are in the category of very convenient for the people of Surabaya.

Recently in a climate where the community aspect is also assessing climate change in a city park is very cool. The results of the questionnaire showed that most people judge the wind cycle is felt in the area of the park is very soothing. Garden shade level during the day is also considered very good. Means of shelter when it rains is also available in the garden area of the city. Based on the questionnaire results also show that the climate aspects included in kaegori very convenient for the city of Surabaya.

Assessment of satisfaction with all aspects of the people of Surabaya to the city park pembangnan overall comfort level of the people of Surabaya there padakategori very comfortable with the percentage of $86.72 \%$. It is therefore reasonable Surabaya get a lot of awards for prestasi their environment such as Verse, Adiwiyata, Kalpataru, ASEAN Environment Sustainable City, and Indonesia Green Region Award 2011.

It can not be separated from community participation and the Department of Infrastructure Development related to the existence of State Parks. People of Surabaya very active role in maintaining the beauty, cleanliness and safety of the park and maintain its existence so good kotaterawat park. Similarly, the relevant agencies in the city park Infrastructure Development play a huge role with professionalism to build, manage and take care of city parks so that conditions in Surabaya city park development to be very beautiful and stay beautiful over time.

\section{CONCLUSION}

Based on the research findings and discussion, it can be concluded as follows:

1. People of Surabaya are very satisfied with the development of a city park. The results of the questionnaire showed the beauty aspect where most people vote against the condition and availability of the facilities available in the garden area is very good and complete.

2. In the aspect of hygiene ratings is also very good people in Surabaya This is shown by the results of a questionnaire in which most of the community assess the condition and availability of clean water and plenty diarea park then cleanliness in the garden area is also very good and the condition of waterways contained in the parks are also good.

3. On security aspects of the community assessment that the security situation is very safe neighborhood park area.

4. In the aspect of public access is also very good ratings. People feel access to the location of the park is very easy. Convenience was also obtained in the activities in the park. 
5. In the aspect of the form of a city park, the community has been very good judge. The results of the questionnaire showed that most respondents assess the condition of facilities and infrastructure is good and complete.

In a climate where the community aspect is also assessing climate change in a city park is very cool. The results of the questionnaire showed that most people judge the wind cycle is felt in the area of the park is very soothing.

\section{REFERENCES}

Direktorat Jenderal Penataan Ruang, Nomor 05, Tahun 2008, tentang Penyediaan dan pemanfaatan ruang terbuka hijau di kawasan perkotaan

Grigg, 2005, Sistem Infrastruktur

Frick, Heinz.2006, Arsitektur Ekologis

Abdillah, J. 2005. Pola Penyebaran Taman Kota

Arifin, H. S. dan Nurhayati H. S, A. (1992) .Perencanaan Taman-Taman Umum

Atmojo, Sunturo Wongso. 2007. Menciptakan Taman Kota Berseri Instruksi Menteri Dalam Negeri No. 14 Tahun 1988. Penataan Ruang. Terbuka Hijau.

Fandy, Tjiptono. 2008. Strategi Pemasaran. Edisi ketiga. CV. Andi OFFSET: Yogyakarta. ,dkk. 2008. Pemasaran Strategik. CV. ANDI OFFSET: Yogyakarta

J. Supranto. 2011. Pengukuran Tingkat KepuasanPelanggan. Jakarta: RinekaCipta

Kotler, Philip danGery Armstrong. Prinsip-prinsippemasaran. Edisi ke-12, Desember 2006.

Kotler, Philip. 2002. ManajemenPemasaran. Edisi 1, Jakarta: Prenhallindo

Sumarwan U, Ahmad Jauzi, Asep Mulyana, Bagio Nugroho Karno, PontiKurniawanMawardi, WahyuNugroho. 2011. RisetPemasarandanKonsumen.CetakanPertama, Bogor, IPB Press.

Supranto, J danNandanLimakrisna. 2011. PerilakuKonsumen\&StrategiPemasaran. Edisikedua-Jakarta :PenerbitMitraWacana Media.

Sofjan, Assauri. ManajemenPemasaran :dasar, konsep, danstrategi; edisike 10, April 2010. https://wisataman.wordpress.com/pesonatamankotasurabaya-tamansurabaya-tamankotataman-kotasurabaya/taman-kota-surabaya-2 